\title{
Plant host habitat and root exudates shape soil bacterial community structure
}

\author{
Feth el Zahar Haichar ${ }^{1}$, Christine Marol $^{1,2}$, Odile Berge ${ }^{1}$, J Ignacio Rangel-Castro ${ }^{3}$, \\ James I Prosser ${ }^{3}$, Jérôme Balesdent ${ }^{1,4}$, Thierry Heulin ${ }^{1}$ and Wafa Achouak ${ }^{1}$ \\ ${ }^{1} C E A, D S V$, iBEB, SBVME, Laboratoire d'Ecologie Microbienne de la Rhizosphère et des Environnements \\ extrêmes (LEMiRE), UMR 6191 CNRS, CEA, Aix Marseille-Univ, FR ECCOREV Saint-Paul-Lez-Durance, \\ France; ${ }^{2}$ CEA Cadarache, DSV/iBEB/SBVME/GRAP, F-13108 Saint Paul Lez, Durance, France; ${ }^{3}$ Institute of \\ Biological and Environmental Sciences, University of Aberdeen, St Machar Drive Aberdeen, Aberdeen, \\ Scotland, UK and ${ }^{4}$ INRA, Unite UR1119 Unite Geochimie des Sols et des Eaux, Aix en Provence, France
}

\begin{abstract}
The rhizosphere is active and dynamic in which newly generated carbon, derived from root exudates, and ancient carbon, in soil organic matter (SOM), are available for microbial growth. Stable isotope probing (SIP) was used to determine bacterial communities assimilating each carbon source in the rhizosphere of four plant species. Wheat, maize, rape and barrel clover (Medicago truncatula) were grown separately in the same soil under ${ }^{13} \mathrm{CO}_{2}\left(99 \%\right.$ of atom $\left.{ }^{13} \mathrm{C}\right)$ and DNA extracted from rhizosphere soil was fractionated by isopycnic centrifugation. Bacteria-assimilating root exudates were characterized by denaturing gradient gel electrophoresis (DGGE) analysis of ${ }^{13} \mathrm{C}$-DNA and root DNA, whereas those assimilating SOM were identified from ${ }^{12} \mathrm{C}$-DNA. Plant species root exudates significantly shaped rhizosphere bacterial community structure. Bacteria related to Sphingobacteriales and Myxococcus assimilated root exudates in colonizing roots of all four plants, whwereas bacteria related to Sphingomonadales utilized both carbon sources, and were identified in light, heavy and root compartment DNA. Sphingomonadales were specific to monocotyledons, whereas bacteria related to Enterobacter and Rhizobiales colonized all compartments of all four plants, used both fresh and ancient carbon and were considered as generalists. There was also evidence for an indirect important impact of root exudates, through stimulation of SOM assimilation by a diverse bacterial community.
\end{abstract}

The ISME Journal (2008) 2, 1221-1230; doi:10.1038/ismej.2008.80; published online 28 August 2008

Subject Category: microbial ecology and functional diversity of natural habitats

Keywords: bacterial community; ${ }^{13} \mathrm{C}$-labelling; rhizosphere; plant species; soil organic matter; root exudates

\section{Introduction}

Plants produce an array of chemical compounds and signalling molecules to defend themselves against harmful organisms and to attract others that are beneficial. These compounds include root exudates that are used by soil bacteria for energy and biomass production. Plants may release up to $20 \%$ of their photosynthesis products into soil, providing the basis for the establishment of plant-microorganism interactions that benefit plant growth by, for example, increasing the availability of mineral nutrients, production of phytohormones, degradation of phytotoxic compounds and suppres-

Correspondence: W Achouak, CEA, DSV, iBEB, SBVME, Laboratoire d'Ecologie Microbienne de la Rhizosphère et des Environnements extrêmes (LEMiRE), UMR 6191 CNRS, CEA, Aix Marseille-Univ, FR ECCOREV Saint-Paul-Lez-Durance F-13108, France.

E-mail: wafa.achouak@cea.fr

Received 27 May 2008; revised 10 July 2008; accepted 10 July 2008; published online 28 August 2008 sion of soil-borne pathogens (Bais et al., 2006). These considerations demonstrate the importance of studying the functional properties of soil microbial communities and the ways in which plant species influence bacterial diversity and microbial activities. Established molecular methods, such as denaturing gradient gel electrophoresis (DGGE), offer valuable insights into the genetic diversity of rhizosphere bacterial communities, and several studies indicate that plants have a strong effect on rhizosphere bacterial community composition (Smalla et al., 2001; Kowalchuk et al., 2002; Costa et al., 2006). This effect is probably linked to root exudates composition (Lynch and Whipps, 1990), which varies with plant species, plant age, location along the root system and soil type (Lupwayi et al., 1998; Yang and Crowley, 2000; Hertenberger et al., 2002). Nevertheless, we lack knowledge of the impact of plant species producing different nutrients and signalling molecules on bacterial populations assimilating root exudates and on how different plant species contribute to 
the use of soil organic matter (SOM) by rhizosphere bacteria.

The recent development of stable isotope probing (SIP) (Radajewski et al., 2000) and its application to tracking plant-derived $\mathrm{C}$ into microbial nucleic acids (Rangel-Castro et al., 2005; Lu et al., 2006; Prosser et al., 2006; Neufeld et al., 2007) or other biochemical markers (Treonis et al., 2004; Paterson et al., 2007) provide the opportunity to understand the functional diversity of plant-associated bacterial communities.

The aim of this study was to identify bacterial communities actively assimilating root exudates in the rhizosphere of four plant species; wheat (Triticum aestivum), maize (Zea mays), rape (Brassica napus) and barrel clover (Medicago truncatula), cultivated in the same soil, by applying DNA-SIP to a ${ }^{13} \mathrm{CO}_{2}$-labelled plants. SIP was employed to distinguish the metabolically active bacterial populations assimilating root exudates from those growing on SOM. We provide evidence that the plant species shape the soil bacterial community structure and that root exudates select certain bacterial species from the bulk soil bacterial community.

\section{Materials and methods}

Plant growth

A laboratory experiment was performed with winter wheat ( $T$. aestivum L. cv Taldor), maize (Z. mays L. cv DEA), rape (B. napus cv. Drakkar) and barrel clover (M. truncatula), ec. J5 on a eutric cambisol soil cultivated from 1993 to 1997 with winter wheat (Derrien et al., 2004). The soil was sieved (1-mm mesh size), air-dried, adjusted to $0.17 \mathrm{~g}$ water per gram dry weight and $40 \mathrm{~g}$ dry weight was placed into polypropylene cylindrical tubes. Seeds of $M$. truncatula were germinated on $0.7 \%(\mathrm{w} / \mathrm{v})$ water agar plates at $25^{\circ} \mathrm{C}$ for $48 \mathrm{~h}$, and maize, rape and wheat seeds were placed in sterile demineralized water for $6 \mathrm{~h}$. After germination, one seedling was planted per pot. Plants were grown in triplicate in a growth chamber (developed and managed by Groupe de Recherche Appliquées en Phytotechnologies, CEA Cadarache, France) equipped for automatic control of light, temperature, moisture, evapotranspiration, irrigation and $\mathrm{CO}_{2}$ concentration. The day-night period was set at $8 / 16$, respectively; light intensity was $400 \mu \mathrm{mol}$ photon $\mathrm{m}^{-2} \mathrm{~s}^{-1}$, maximum daily temperature ranged from 20 to $22{ }^{\circ} \mathrm{C}$, air moisture was adjusted at $80 \%$ and $\mathrm{CO}_{2}$ concentration was maintained at $350 \mu \mathrm{ll}^{-1}$. Soil moisture was manually controlled. Triplicate pots with soil but without plants (bulk soil treatment) were incubated under the same conditions.

\footnotetext{
${ }^{13} \mathrm{C}$ enrichment

Continuous labelling was initiated 1 week after sowing seeds. $\mathrm{CO}_{2}$ partial pressure was assured by injection of pure $\left(>99 \%\right.$ atom $\left.{ }^{13} \mathrm{C}\right){ }^{13} \mathrm{CO}_{2}$ (purchased
}

from Cortec Net, Paris, France) during active photosynthesis. The isotope excess of $\mathrm{CO}_{2}$ and the partial pressure in the chamber were continuously monitored by near infra-red spectroscopy. To avoid dilution of ${ }^{13} \mathrm{CO}_{2}$ by ${ }^{12} \mathrm{CO}_{2}$ from soil respiration, the $\mathrm{CO}_{2}$ concentration of the chamber was lowered to $400 \mathrm{\mu l} \mathrm{l}^{-1}$ at the end of the night period by automatic gas trapping using $\mathrm{NaOH} .{ }^{13} \mathrm{CO}_{2}$ was then quickly injected, so that $\mathrm{CO}_{2}$ concentration reached $350 \mu \mathrm{ll}^{-1}$. The isotope excess in the chamber was maintained at $>80 \%$ atom ${ }^{13} \mathrm{C}$ during the first 10 days and $>90 \%$ atom ${ }^{13} \mathrm{C}$ thereafter. Wheat, maize, rape and barrel clover plants were harvested 23, 25, 36 and 34 days after ${ }^{13} \mathrm{C}$ labelling, respectively. Soil microcosms were harvested after 36 days of ${ }^{13} \mathrm{CO}_{2}$ labelling.

\section{DNA extraction and gradient fractionation}

At the end of labelling, the roots of each plant were separated from the rhizosphere soil, which was collected and frozen in liquid $\mathrm{N}_{2}$ immediately and stored at $-80^{\circ} \mathrm{C}$. The root systems were manually separated from the soil and carefully washed with $0.025 \mathrm{M} \mathrm{K}_{2} \mathrm{SO}_{4}$ to remove adhering soil particles. Root material was frozen in liquid $\mathrm{N}_{2}$ and stored at $-80^{\circ} \mathrm{C}$. DNA was extracted as described by Ranjard et al. (2003) from $5 \mathrm{~g}$ rhizosphere soil or $1 \mathrm{~g}$ of root system from each plant. DNA was quantified by electrophoresis in a 1\% agarose gel. DNA extracted from roots was derived from endophytic microorganisms and from microorganisms firmly attached to the root surface. Extracted DNA was fractionated by $\mathrm{CsCl}$ equilibrium density-gradient centrifugation (Lueders et al., 2004; Haichar et al., 2007). Each fraction was weighed to determine buoyant density, and DNA was quantified using Picogreen assays (Molecular Probes, Eugene, OR, USA). Nucleic acids were purified from CsCl salts using Geneclean Kit (Qbiogene, Montreal, Canada).

\section{${ }^{13} \mathrm{C}$ analysis \\ The ${ }^{13} \mathrm{C}$ enrichment of heavy and light DNA fractions} was measured by isotope ratio mass spectrometry $(\delta+$ ThermoFinnigan) coupled with an elemental analyser $(\delta+$ and Conflo, ThermoFinnigan, Thermo-Electron Corp., Bremen). One to two microgram of DNA was placed into $5 \times 9$-mm tin capsules (Elemental Microanalysis, Okehampton, UK), dried for $2 \mathrm{~h}$ at $60^{\circ} \mathrm{C}$ and submitted for mass spectrometry (Haichar et al., 2007). $\delta{ }^{13} \mathrm{C}(\%)$ was determined using the equation:

$$
\delta^{13} \mathrm{C}(\% \mathrm{o})=\left[\left(R_{\text {sample }}-R_{\text {standard }}\right)-1\right] \times 1000
$$

where $R={ }^{13} \mathrm{C} /{ }^{12} \mathrm{C}$. The $R_{\text {standard }}$ was Pee Dee Belemnite (Wang and Hsieh, 2002).

The ${ }^{13} \mathrm{C}$ content of heavy and light DNA fractions extracted from the rhizosphere soil of each plant after isopycnic separation were reported in ${ }^{13} \mathrm{C}$ at percentage units obtained using the equation:

$$
{ }^{13} \mathrm{C} \text { atom } \%=\left(\frac{R}{R}+1\right) \times 100
$$


and represents the average between DNA fractions for triplicate plants.

Denaturing gradient gel electrophoresis fingerprinting and principal component analysis (PCA)

$16 \mathrm{~S}$ rRNA gene fragments were amplified using a nested PCR approach according to Rangel-Castro et al. (2005). DGGE analysis of PCR products from root DNA of each plant and from light and heavy DNA fractions from rhizosphere soil of each plant was carried out using the Dcode Universal Mutation Detection System (BIO-Rad, Hercules, CA, USA) according to Haichar et al. (2007). Following electrophoresis, the gels were silver-stained and scanned (McCaig et al., 2001). ImageQuant TL onedimensional gel analysis software (version v2003, Amersham Biosciences, Amersham, UK) was used to determine band presence and intensity as described by McCaig et al. (2001). The DGGE data matrices obtained were analysed using PCA ADE-4 software (Thioulouse et al., 1997). Statistical ellipses representing $90 \%$ confidence on PCA plots were used to compare the DGGE profiles statistically.

Criteria for DGGE bands selection and characterization PCR products of triplicates were pooled and were analysed by DGGE. Criteria used when choosing DGGE bands were the exclusive presence or a significantly higher intensity in one compartment (in the triplicates). When R, H, L (Root, Heavy and Light DNA fractions) are listed in the same line from Table 1, it means that the band was present in the three compartments, and thus was excised from the three compartments and sequenced to be sure that the band in the same position corresponded to the same bacterial population. When only one compartment is indicated ( $\mathrm{L}$ or $\mathrm{H}$ or R), the bacterial population was present only in the indicated compartment of the corresponding plant. Bands were excised from DGGE gels and identified according to Haichar et al. (2007). Certain bands required cloning using the Topo PCR cloning kit (Invitrogen Life Technologies, Carlsbad, CA, USA). Transformed colonies with the correct insert were subjected to PCR amplification using primers 357f-GC and 518r (Muyzer et al., 1993) and the products were screened using DGGE as described above.

\section{Sequencing and BLAST analysis}

PCR products were sequenced with 518r primer (Muyzer et al., 1993) at Genome express (Meylan, France) and sequences were analysed by the BLASTN search tool (Altschul et al., 1990) to determine the most similar sequences in the GenBank database. The sequences from this study were deposited to GenBank under the accession numbers (EF554929-EF554950) for wheat, (EF554987EF555020) for maize, (EF555021-EF555038) for barrel clover and (EF555039-EF555065) for rape.

\section{Results}

Microbial assimilation of ${ }^{13} \mathrm{C}$ root exudates

To confirm the assimilation of ${ }^{13} \mathrm{C}$-root exudates by soil bacteria, DNA extracted from each rhizosphere soil was fractionated by isopycnic centrifugation and fractions along the gradient were analysed for $\delta^{13} \mathrm{C}$. Figure 1 shows an example of the partitioning of DNA and ${ }^{13} \mathrm{C}$ labelling among gradient fractions of increasing density with DNA extracted from the rape rhizosphere soil. The DNA density profile shows a unique peak ranging from 1.61 to 1.63 , and ${ }^{13} \mathrm{C}$-labelling measured by isotope ratio mass spectrometry increased slightly in the light fractions before increasing significantly, showing the presence of labelled DNA between 1.65 and 1.68 densities (Figure 1). Similar profiles were obtained for DNA extracted from the rhizosphere soil of the other plant species. DGGE analysis was performed on all fractions and one fraction corresponding to a buoyant density of $1.63 \mathrm{~g} \mathrm{ml}^{-1} \mathrm{CsCl}$ was selected as representative of the light DNA, representing bacterial populations not involved in assimilation of ${ }^{13} \mathrm{C}$-root exudates. A fraction corresponding to a buoyant density of $1.67 \mathrm{~g} \mathrm{ml}^{-1} \mathrm{CsCl}$ was selected as representative of the heavy DNA, and of bacteria actively assimilating ${ }^{13} \mathrm{C}$-root exudates. The ${ }^{13} \mathrm{C}$ content of theses fractions was $\sim 1.09 \%$ for light DNA fractions and 1.28, 1.25, 1.20 and $1.21 \%$ for heavy DNA fractions of wheat, rape, maize and barrel clover, respectively. ${ }^{13} \mathrm{C}$ levels were significantly greater in heavy DNA fractions than in light DNA fraction values for the four plants, indicating ${ }^{13} \mathrm{C}$-labelled incorporation into the rhizosphere microbial community.

\section{Active bacterial community associated with root exudation}

To investigate the impact of nutrients and/or signalling compounds produced by each plant species on the bacterial community, three DNA fractions from the rhizosphere of each plant were analysed by $16 \mathrm{~S}$ rRNA-gene-based DGGE: heavy DNA, light DNA and DNA from root tissues in comparison to the bulk soil. Experiments were performed in triplicate and quite similar DGGE profiles were observed for each fraction of triplicates, demonstrating reasonable reproducibility (Supplementary Figure S1). DGGE profiles generated from heavy and light DNA fractions from bulk soil consisted of a few strong bands and a large number of fainter bands, whereas profiles generated from heavy and light DNA fractions from rhizosphere soil showed an increase in relative abundance of several bands and the appearance of new bands.

Denaturing gradient gel electrophoresis profiles from heavy DNA fractions from rape and barrel clover rhizosphere soil were significantly different from the corresponding light DNA fractions, with the appearance of some bands and increase in 
Table 1 Phylogenetic affiliation of partial bacterial 16S rRNA gene sequences corresponding to DGGE prominent bands retrieved from root DNA (R), heavy (H) and light (L) DNA fractions of wheat, maize, rape and barrel clover plants

\begin{tabular}{|c|c|c|c|c|c|c|c|}
\hline & & $\begin{array}{l}\text { BLAST closet } \\
\text { match }\end{array}$ & $\begin{array}{l}\text { Percentage } \\
\text { of similarity }\end{array}$ & Wheat & Maize & Rape & $\begin{array}{l}\text { Barrel } \\
\text { clover }\end{array}$ \\
\hline \multicolumn{8}{|l|}{ Phylogenetic group } \\
\hline \multirow{2}{*}{ Enterobacteriales } & & Pantoea agglomerans & 100 & $\begin{array}{l}\mathrm{R}^{\mathrm{a}} \\
\mathrm{R}\end{array}$ & $\mathrm{R}, \mathrm{H} \mathrm{I}$ & & DU \\
\hline & & Escherichia coli & 99 & & R, H, L & $\begin{array}{l}\mathrm{N}, \mathrm{H}, \mathrm{L} \\
\mathrm{R}\end{array}$ & $\mathrm{K}, \Pi, \mathrm{L}$ \\
\hline \multirow[t]{2}{*}{ Pseudomonadales } & & Pseudomonas sp. & 99 & & & $\mathrm{R}, \mathrm{H}^{\mathrm{a}}$ & \\
\hline & Moraxellaceae & $\begin{array}{l}\text { Acinetobacter } \\
\text { calcoaceticus }\end{array}$ & 98 & $\mathrm{H}, \mathrm{L}$ & & $\mathrm{R}$ & \\
\hline \multirow[t]{10}{*}{ Xanthomonadales } & Xanthomonadaceae & Pseudoxanthomonas sp. & 97 & & & $\mathrm{H}, \mathrm{L}$ & $\mathrm{H}$ \\
\hline & & $\begin{array}{l}\text { Pseudoxanthomonas } \\
\text { mexicana }\end{array}$ & 100 & $\mathrm{R}, \mathrm{H}, \mathrm{L}$ & & & \\
\hline & & Lysobacter ginsengisoli & 100 & & & $\mathrm{H}, \mathrm{L}^{\mathrm{a}}$ & \\
\hline & & $\begin{array}{l}\text { Uncultured } \\
\text { Lysobacter sp. }\end{array}$ & 100 & $\mathrm{H}, \mathrm{L}^{\mathrm{a}}$ & & & \\
\hline & & Thermomonas brevis & 99 & & $\mathrm{R}, \mathrm{H}, \mathrm{L}^{\mathrm{a}}$ & & \\
\hline & & Rhodanobacter terrae & 98 & $\mathrm{~L}^{\mathrm{a}}$ & & & \\
\hline & & Dokdonella Koreensis & 96 & & $\mathrm{R}^{\mathrm{a}}$ & & \\
\hline & & $\begin{array}{l}\text { Stenotrophomonas } \\
\text { sp. MFC-C }\end{array}$ & 100 & $\mathrm{R}$ & & & $\mathrm{R}$ \\
\hline & & Stenotrophomonas sp. & 100 & & $\mathrm{~L}$ & & $\mathrm{R}$ \\
\hline & & $\begin{array}{l}\text { Stenotrophomonas } \\
\text { maltophilia }\end{array}$ & 99 & & $\mathrm{H}^{\mathrm{a}}$ & & \\
\hline \multicolumn{8}{|l|}{ Alphaproteobacteria } \\
\hline \multirow[t]{2}{*}{ Caulobacterales } & Caulobacteraceae & Caulobacter vibrioides & 100 & $\mathrm{R}, \mathrm{H}, \mathrm{L}^{\mathrm{a}}$ & $\mathrm{T}$ & $\mathrm{I}$ & \\
\hline & & $\begin{array}{l}\text { Brevundimonas sp. 7-4 } \\
\text { Uncultured }\end{array}$ & $\begin{array}{r}100 \\
98\end{array}$ & $\begin{array}{l}\mathrm{H}, \mathrm{L} \\
\mathrm{H}, \mathrm{L}^{\mathrm{a}}\end{array}$ & $\mathrm{H}, \mathrm{L}$ & $\mathrm{L}$ & \\
\hline \multirow[t]{12}{*}{ Rhizobiales } & Rhizobiaceae & & & & & & \\
\hline & & Rhizobium sp. & 100 & & & & $\mathrm{R}^{\mathrm{a}}$ \\
\hline & & $\begin{array}{l}\text { Rhizobium } \\
\text { leguminosarum }\end{array}$ & 99 & & & & $\mathrm{R}^{\mathrm{a}}$ \\
\hline & & Rhizobium giardinii & 100 & & $\mathrm{H}^{\mathrm{a}}$ & & \\
\hline & & Rhizobium etli & 100 & & & & $\mathrm{R}^{\mathrm{a}}$ \\
\hline & & $\begin{array}{l}\text { Rhizobium sp. } \\
\text { R31549 }\end{array}$ & 98 & $\mathrm{R}, \mathrm{H}, \mathrm{L}$ & $\mathrm{R}, \mathrm{L}$ & $\mathrm{R}, \mathrm{H}$ & $\mathrm{L}$ \\
\hline & & $\begin{array}{l}\text { Agrobacterium } \\
\text { tumefaciens }\end{array}$ & 98 & & $\mathrm{R}$ & & $\mathrm{R}$ \\
\hline & & $\begin{array}{l}\text { Ensifer, Sinorhizobium } \\
\text { meliloti; } C C B A U 81180\end{array}$ & 100 & $\mathrm{R}$ & $\mathrm{R}, \mathrm{L}$ & & $\mathrm{R}$ \\
\hline & Phylobacteriaceae, & $\begin{array}{l}\text { Chelarovorus } \\
\text { multitrophus }\end{array}$ & 98 & & & & $\mathrm{R}^{\mathrm{a}}$ \\
\hline & Bradyrhizobiaceae & Bradvrhizobium sp. & 98 & & & $\mathrm{R}, \mathrm{H}^{\mathrm{a}}$ & \\
\hline & Brucellaceae & Ochrobacterium sp. & 100 & & $\mathrm{R}$ & $\mathrm{H}$ & \\
\hline & & Ochrobactrum tritici & 98 & & & & $\mathrm{R}^{\mathrm{a}}$ \\
\hline \multirow[t]{4}{*}{ Sphingomonadales } & Sphingomonadaceae & & & & & & \\
\hline & & Sphingopyxis sp. & 100 & $\mathrm{R}, \mathrm{H}, \mathrm{L}^{\mathrm{b}}$ & $\mathrm{H}, \mathrm{L}^{\mathrm{b}}$ & & \\
\hline & & $\begin{array}{l}\text { Sphingomonas } \\
\text { suberfaciens }\end{array}$ & 100 & & $\mathrm{R}^{\mathrm{a}}$ & & \\
\hline & Erythrobacteraceae & Erythrobacter sp. & 97 & $\mathrm{H}, \mathrm{L}^{\mathrm{b}}$ & $\mathrm{R}, \mathrm{H}^{\mathrm{b}}$ & & \\
\hline \multirow[t]{2}{*}{ Rhodospirillales } & Rhodospirillaceae & Azospirillum oryzae & 100 & & $\mathrm{R}, \mathrm{H}^{\mathrm{a}}$ & & \\
\hline & & Magnetospirillum sp. & 100 & & & & $\mathrm{H}^{\mathrm{a}}$ \\
\hline \multicolumn{3}{|c|}{$\alpha$-Proteobacterium, uncultured rape rhizosphere bacterium wr0019 } & 98 & $\mathrm{R}^{\mathrm{b}}$ & $\mathrm{R}^{\mathrm{b}}$ & & \\
\hline \multirow{9}{*}{$\begin{array}{l}\beta \text {-Proteobacteria } \\
\text { Burkholderiales }\end{array}$} & & & & & & & \\
\hline & Comamorrdaceae & Simplicispira sp. & 100 & $\mathrm{R}, \mathrm{H}, \mathrm{L}$ & & $\mathrm{H}, \mathrm{L}$ & \\
\hline & & Variovorax paradoxus & 100 & & & $\mathrm{R}^{\mathrm{a}}$ & \\
\hline & & Acidovorax sp. & 100 & & & $\mathrm{H}^{\mathrm{a}}$ & \\
\hline & Oxalobacteraceae & Janthinobacterium sp & 100 & $\mathrm{H}, \mathrm{L}^{\mathrm{b}}$ & $\mathrm{R}^{\mathrm{b}}$ & & \\
\hline & & Oxalobacter sp. & 99 & & & $\mathrm{R}$ & $\mathrm{R}$ \\
\hline & & Xylophilus ampelinus & 99 & & $\mathrm{H}^{\mathrm{a}}$ & & \\
\hline & & Uncultured & 98 & & $\mathrm{H}$ & $\mathrm{R}$ & \\
\hline & & $\begin{array}{l}\text { Oxalobacteraceae } \\
\text { bacterium }\end{array}$ & & & & & \\
\hline
\end{tabular}


Table 1 Continued

\begin{tabular}{|c|c|c|c|c|c|c|c|}
\hline & & $\begin{array}{l}\text { BLAST closet } \\
\text { match }\end{array}$ & $\begin{array}{l}\text { Percentage } \\
\text { of similarity }\end{array}$ & Wheat & Maize & Rape & $\begin{array}{l}\text { Barrel } \\
\text { clover }\end{array}$ \\
\hline & Burkholderiaceae & $\begin{array}{l}\text { Burkholderia } \\
\text { thailandensis }\end{array}$ & 97 & & $\mathrm{R}^{\mathrm{a}}$ & & \\
\hline & Rhodocyclaceae & Azospira oryzae & 99 & & & $\mathrm{R}^{\mathrm{a}}$ & \\
\hline \multicolumn{8}{|l|}{$\delta$-proteobacteria } \\
\hline Myxococcales & & $\begin{array}{l}\text { Myхососcus } \\
\text { macrosporus }\end{array}$ & 99 & $\mathrm{R}$ & $\mathrm{R}$ & $\mathrm{R}$ & $\mathrm{R}$ \\
\hline \multicolumn{8}{|l|}{ Bacteroidetes } \\
\hline \multirow[t]{3}{*}{ Sphingobacteriales } & & $\begin{array}{l}\text { Flexibacteriaceae } \\
\text { bacterium JJ-1521 }\end{array}$ & 100 & $\mathrm{R}$ & $\mathrm{R}$ & $\mathrm{R}$ & $\mathrm{R}$ \\
\hline & & $\begin{array}{l}\text { Kaistomonas } \\
\text { ginsengisoli }\end{array}$ & 97 & $\mathrm{R}^{\mathrm{b}}$ & $\mathrm{R}^{\mathrm{b}}$ & & \\
\hline & & Dyadobacter fermentans & 100 & $\mathrm{R}$ & & $\mathrm{R}$ & \\
\hline \multicolumn{8}{|l|}{ Frimicutes } \\
\hline Bacillales & Paenibacillaceae & $\begin{array}{l}\text { Paenibacillus graminis } \\
\text { Paenibacillus } \\
\text { thailandensis }\end{array}$ & $\begin{array}{r}100 \\
99\end{array}$ & R, H, L & $\mathrm{R}$ & $\mathrm{R}, \mathrm{H}, \mathrm{L}$ & $\mathrm{R}^{\mathrm{a}}$ \\
\hline Uncultured & Firmicutes bacterium & & 97 & & & & $\mathrm{R}^{\mathrm{a}}$ \\
\hline \multicolumn{8}{|l|}{ Actinobacteria } \\
\hline \multirow[t]{5}{*}{ Actinomycetales } & $\begin{array}{l}\text { Streptomycineae } \\
\text { Microbacteriaceae }\end{array}$ & $\begin{array}{l}\text { Streptomyces sp. } \\
\text { Clavibacter sp. }\end{array}$ & $\begin{array}{l}97 \\
99\end{array}$ & & $\mathrm{R}$ & $\mathrm{H}^{\mathrm{a}}$ & $\mathrm{R}$ \\
\hline & мнсторастептасеае & Micrococcus sp. & $\begin{array}{l}99 \\
99\end{array}$ & & $\mathrm{H}, \mathrm{L}^{\mathrm{a}}$ & $\Pi$ & \\
\hline & & $\begin{array}{l}\text { Microbacterium } \\
\text { arabinogalactano- } \\
\text { lyticum }\end{array}$ & 100 & & $\mathrm{H}, \mathrm{L}^{\mathrm{a}}$ & & \\
\hline & & Microbacterium sp. & 97 & & & $\mathrm{H}^{\mathrm{a}}$ & \\
\hline & Micrococcaceae & Arthrobacter sp. & 99 & & $\mathrm{H}, \mathrm{L}^{\mathrm{a}}$ & & \\
\hline Uncultured & Actinobacterium & & 97 & & & $\mathrm{R}^{\mathrm{a}}$ & \\
\hline Verrucomicrobia & & & & & & & \\
\hline Verrucomicrobiales & Verrucomicrobiaceae & $\begin{array}{l}\text { Uncultured } \\
\text { Verrucomicrobia } \\
\text { bacterium }\end{array}$ & & & & $\mathrm{H}, \mathrm{L}^{\mathrm{a}}$ & \\
\hline
\end{tabular}

aSpecific bacterial species selected by each plant rhizosphere.

bBacterial species found only in monocotyledon plants rhizosphere (wheat and maize).

relative intensities of others (Figure 2 and Supplementary Figure S2). These results indicate that specific bacterial populations were actively incorporating ${ }^{13} \mathrm{C}$-root exudates. In contrast, there were no significant differences between DGGE profiles derived from heavy and light DNA fractions of wheat and maize rhizosphere soil (Figure 2 and Supplementary Figure S2).

Denaturing gradient gel electrophoresisprofiles derived from plant root tissue were complex (Figure 2). Some bands corresponding to sequences with low GC percentage were present in all root profiles and others, corresponding to sequences with high GC percentage were specific to each plant (Figure 2). DGGE profiles from root tissues differed significantly from those of the heavy and light DNA fractions derived from rhizosphere soil of each plant, with the appearance of several new bands (Figure 2 and Supplementary Figure S2).

The significance of plant species effects on the structure of bacterial communities in the heavy and light DNA fractions from rhizosphere soil and in root tissues, in comparison with bulk soil, was characterized with PCA (Supplementary Figure S3). DGGE profiles derived from light DNA fractions contained some bands, which were absent from DNA fractions from bulk soil (Figure 2). PCA of DGGE profiles from light DNA fractions of each plant rhizosphere soil and bulk soil (Supplementary Figure S3A) indicated significant differences in bacterial community structure, suggesting that a proportion of the rhizosphere soil community was active through the utilization of SOM.

Denaturing gradient gel electrophoresis profiles from heavy DNA fractions associated with rape differed significantly from those of barrel clover and wheat, in addition, barrel clover differed significantly from the other plants, whereas wheat and maize were not significantly different (Supplementary Figure S3B). In contrast, bacterial communities from root tissues of maize, wheat, rape and barrel clover were significantly different (Supplementary Figure S3C). 


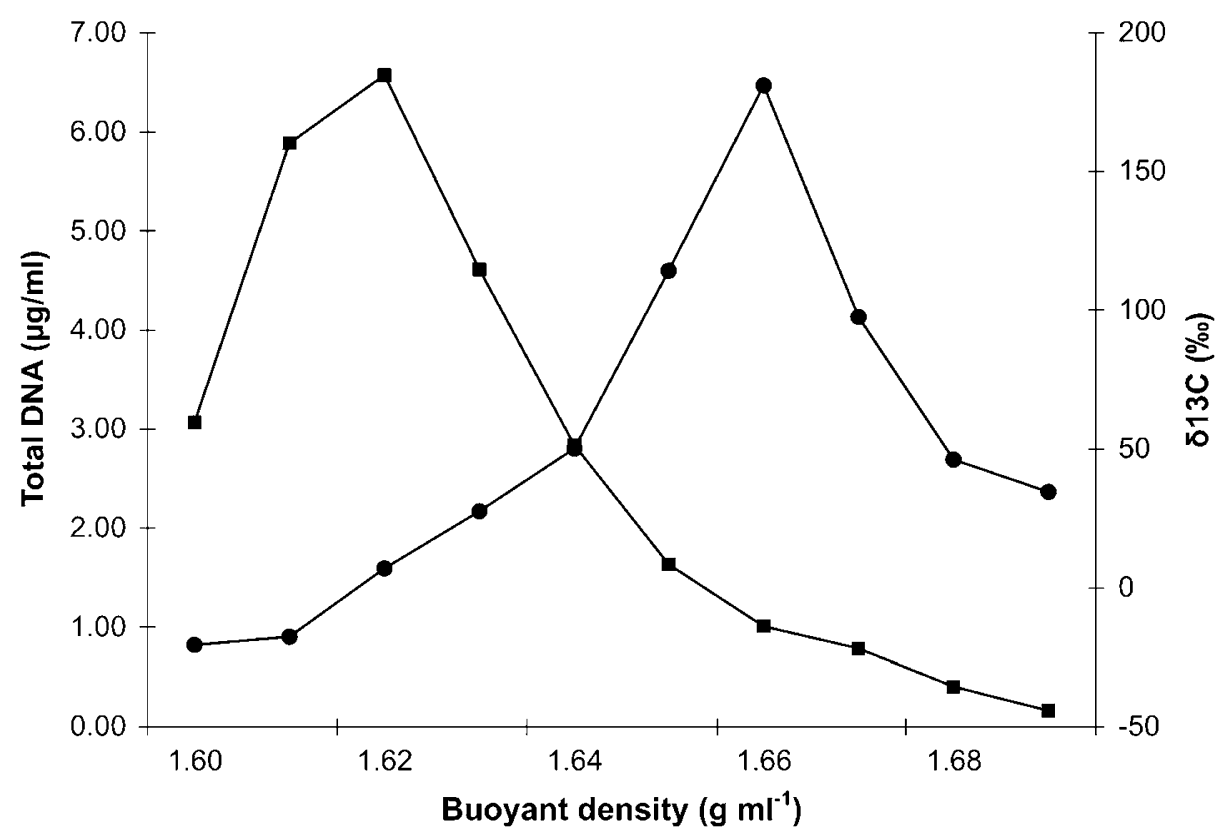

Figure 1 Incorporation of ${ }^{13} \mathrm{C}$-labelled root exudates into DNA of microbial communities derived from rhizosphere soil of rape (Brassica napus). Heavy and light DNA were separated by $\mathrm{CsCl}$ density-gradient centrifugation and total DNA in gradient fractions (5-14) was quantified fluorimetrically ( $\mathbf{\square})$ and ${ }^{13} \mathrm{C}$ incorporation by infra-red mass spectroscopy ( $)$ ).

Plant-dependent bacterial communities

The major bacterial groups stimulated by rape plant root exudates were $\alpha-, \delta$-, $\gamma$ - and $\beta$-proteobacteria and members of the Actinobacteria (Table 1). Rootassociated bacterial populations were diverse, and certain bacterial species closely related to Azospira, Acidovorax and Variovorax species were found only in association with rape plant. Barrel clover root exudates stimulated $\alpha$ - and $\gamma$-proteobacteria and members of the Actinobacteria and, unlike other plants, root tissues were preferentially colonized by rhizobiales (Table 1). Some slight differences were observed between DGGE profiles from heavy and light DNA fractions for maize rhizosphere soil (Figure 2), with stimulation of Actinobacteria and $\gamma$-, $\alpha$ - and $\beta$-proteobacteria (Table 1). Bacteria from the major divisions colonized maize root tissues with a specific selection of organisms closely related to Azospirillum, Sphingomonas and Dokdonella species, which were not found in the rhizosphere of the other plants. DGGE profiles from light and heavy DNA fractions of wheat were very similar (Figure 2), with colonization of the rhizosphere from major bacterial divisions, with the exception of Actinobacteria (Table 1). DGGE profiles from wheat root tissues was diverse (Figure 2). Certain bacterial species closely related to Pantoea, Dyadobacter and Kaistomonas species were detected only on root tissues (Table 1).

\section{Discussion}

Microbial community inhabiting rhizosphere soil The rhizosphere is a dynamic environment whose distribution of resources varies in space and time

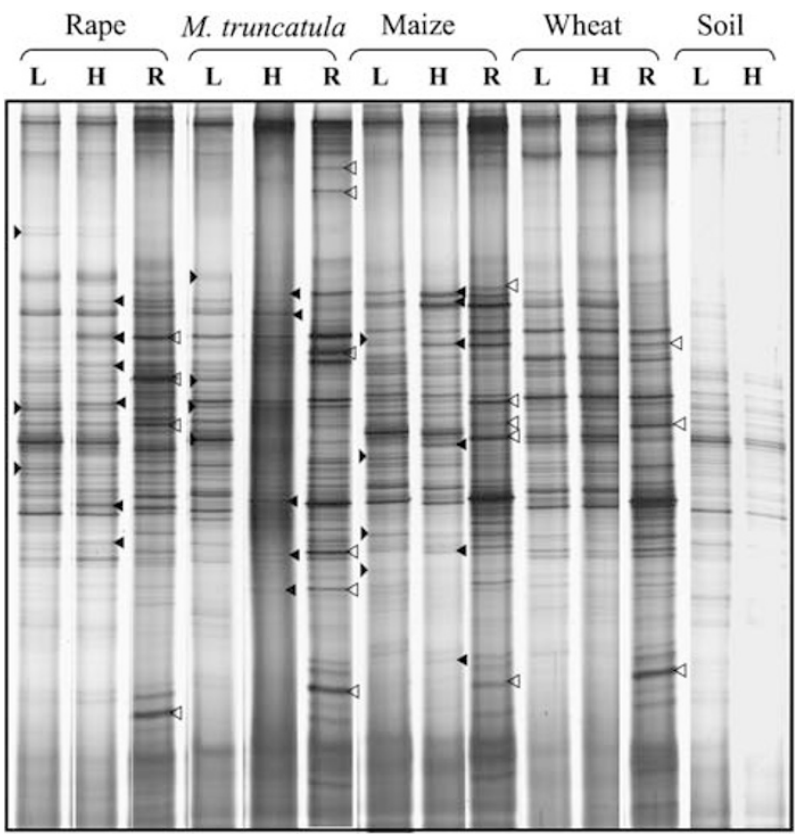

Figure 2 DGGE banding profiles of bacterial 16S rRNA genes PCR-amplified from light DNA (unlabelled, L), heavy DNA (labelled, $\mathrm{H}$ ) and root DNA (R) fractions obtained from ${ }^{13} \mathrm{CO}_{2}$ labelled barrel clover (Medicago truncatula), rape (Brassica napus), maize (Zea mays) and wheat (Triticum aestivum) plants. Black left and right directing arrowheads indicate examples of bands that appeared or increased in relative intensity in heavy or light DNA fractions, respectively. White arrowheads designate examples of bands that were associated with root tissues only. DGGE, denaturing gradient gel electrophoresis.

(Yang and Crowley, 2000). Plants provide a variety of carbon and energy sources, which are thought to influence microbial populations in a plant-specific 
manner (Costa et al., 2006). Isotope ratio mass spectrometry and DGGE analyses demonstrated ${ }^{13} \mathrm{C}$-labelling of bacterial DNA, confirming in situ assimilation and growth at the expense of ${ }^{13} \mathrm{C}$-root exudates in the rhizosphere.

In this study, we aimed to determine the extent of plant species impact on bacterial structure organization based on the nature of assimilated carbon and the habitat selection (soil versus roots).

\section{Priming effect}

Significant differences were observed between DGGE profiles generated from light DNA fractions derived from rhizosphere soil of maize, rape, barrel clover and wheat, and also from bulk soil (Figure 2 and Supplementary Figure S3A), indicating an indirect impact of root exudates on bacterial communities. Unlabelled but reactive populations probably correspond to organisms specialized in the degradation of refractory SOM (Fontaine et al., 2003) and organisms such as Brevundimonas, Rhodanobacter, Stenotrophomonas and certain rhizobia may use root exudates as an energy source and then produce SOM degrading enzymes, enabling growth at the expense of SOM (Table 1).

The presence of certain bands migrating at the same level in DGGE profiles derived from heavy and light DNA fractions were analysed, and obtained sequences were identical, suggesting that multiple genotypes of the same species can occur in a single soil, as reported in relation to crop management (Achouak et al., 2000) and in Arabidopsis thaliana and wheat rhizospheres (Fromin et al., 2001). Our results provide evidence that certain genotypes are assimilating root exudates, whereas others benefit directly from refractory SOM or from compounds derived from SOM partially degraded by specialized bacteria. These results emphasize the importance of the indirect impact of the rhizosphere in the turnover of SOM. Moreover, roots of certain plants release exoenzymes and organic acids, which contribute to SOM degradation (Gramss and Rudeschko, 1998; Kuzyakov, 2002; Kumar et al., 2006). Therefore, plants with well-developed and branched root system might accelerate SOM decomposition (Kuzyakov, 2002) and consequently provide organic substrates for microbial communities.

Denaturing gradient gel electrophoresis profiles from heavy and light DNA fractions derived from wheat rhizosphere soil were very similar (Figure 2 and Supplementary Figure S2C) suggesting that wheat increases SOM degradation by the exudation of exoenzymes and Billès and Bottner (1981) showed that $60 \%$ of ${ }^{14} \mathrm{C}$-labelled root litter was decomposed during early wheat growth. Continuous labelling of plants with ${ }^{13} \mathrm{CO}_{2}$ enabled investigation of root-exudate-mediated priming effects in the rhizosphere and identification of microorganisms responsible for the degradation of SOM. However, we cannot exclude that certain slow growing bacteria may be retrieved from the light fraction, althought they are assimilating root exudates, because they did not yet divide. In this case, RNASIP may circumvent this limitation because of their higher turnover rate and would be more appropriate.

\section{Root exudate assimilation}

The main interest of SIP is to associate phylogeny with environmental functions. SIP of root exudates in the rhizosphere of different plant species enabled the identification of bacteria that benefit from fresh carbon released by roots of four plant species in the rhizosphere. It is worth to determine whether plants feed only beneficial soil-borne bacteria.

DNA-SIP combined with DGGE analysis of small subunit rRNA gene (rrs) fragments enabled the characterization of bacterial communities assimilating root exudates. The continuous labelling of plant and consequent labelling of root exudates allowed sufficient ${ }^{13} \mathrm{C}$ enrichment of bacterial DNA. Sequences corresponding to the most variable region of rrs, although their short length (200 bp) enabled bacterial identification at genus level.

Some of the bacterial species assimilating root exudates were closely related to bacteria known for their beneficial effect on plant growth and/or protection against phytopathogens, whereas others have previously been shown to be pathogens of plants or animals. Certain bacteria are considered as beneficial, because they produce phytohormones (Azospirillum and Pseudomonas) (Mantelin and Touraine, 2004; Preston, 2004) and antifungal compounds (Stenotrophomonas, Pseudomonas and Microbacterium) (Preston, 2004; Kai et al., 2007; Zachow et al., 2008) or contribute to biogeochemical cycling of sulphur (Acidovorax) (Schmalenberger and Kertesz, 2007) or nitrogen, as diazotrophs and denitrifiers (Azospirillum) (Costacurta and Vanderleyden, 1995). Bacteria considered as human opportunistic pathogens, such as Stenotrophomonas maltophilia, Enterobacter cloacae (Berg et al., 2005) or vine phytopathogenic bacteria, such as Xylophilus ampelinus (Grall and Manceau, 2003), were able to assimilate root exudates and to proliferate in the rhizosphere of different plant species. The rhizosphere, therefore, constitutes a reservoir of beneficial and pathogenic bacteria.

Bacterial communities associated with plant roots The majority of studies of plant communities have focused on rhizosphere soil, defined as soil that is influenced by plant roots (Smalla et al., 2001; Kuske et al., 2002; Costa et al., 2006), and few have investigated root tissue communities as a distinct ecological niche (Marilley and Aragno, 1999; Nunan 
Table 2 Examples of active bacteria associated with root exudates in the rhizosphere of wheat, maize, rape and barrel clover plants

\begin{tabular}{|c|c|c|c|c|c|}
\hline Active bacteria & $\begin{array}{l}\text { Phylogenetic groups } \\
\text { (BLAST closest match) }\end{array}$ & Wheat & Maize & Rape & $\begin{array}{l}\text { Barrel } \\
\text { clover }\end{array}$ \\
\hline Generalist bacteria & $\begin{array}{l}\text { Enterobacter } \\
\text { Rhizobiales }\end{array}$ & $\begin{array}{l}\text { R, H, L } \\
\text { R, H, L }\end{array}$ & $\begin{array}{l}\text { R, H, L } \\
\text { R, H, L }\end{array}$ & $\begin{array}{c}\text { R, H, L } \\
\text { R, H }\end{array}$ & $\begin{array}{l}\mathrm{R}, \mathrm{H}, \mathrm{L} \\
\mathrm{R}\end{array}$ \\
\hline \multirow{2}{*}{$\begin{array}{l}\text { Wide host range } \\
\text { root-associated bacteria }\end{array}$} & Myхососсиs & $\mathrm{R}$ & $\mathrm{R}$ & $\mathrm{R}$ & $\mathrm{R}$ \\
\hline & Sphingobacteriales & $\mathrm{R}$ & $\mathrm{R}$ & $\mathrm{R}$ & $\mathrm{R}$ \\
\hline \multirow{2}{*}{$\begin{array}{l}\text { Specific plant bacteria } \\
\text { association }\end{array}$} & Acidovorax & & & $\mathrm{H}$ & \\
\hline & $\begin{array}{l}\text { Variovorax } \\
\text { Burkholderia } \\
\text { Sphingomonadaceae }\end{array}$ & $\mathrm{R}$ & $\begin{array}{l}\mathrm{R} \\
\mathrm{R}\end{array}$ & $\mathrm{R}$ & \\
\hline
\end{tabular}

H, L and R correspond to heavy, light and root DNA fractions, respectively.

et al., 2005). Bacterial communities associated with root tissues differed significantly from those of rhizosphere soil for the four plants investigated here, indicating specific recognition and nutritional selection of bacterial communities on root tissues, before diffusion of nutrients into the rhizosphere soil. Several bacteria closely related to Kaistomonas, Dyadobacter, Streptomyces, Sphingomonas, Variovorax and Azospira species specifically colonized root tissues of plants. These bacteria are known to interact with plants and may exchange signalling molecules and utilize readily secreted compounds. Their proximity to the plant might also be beneficial for the plant, as bacterial-reactive molecules, such as phytohormones, may act more efficiently in the vicinity of roots. Azospira species are known to produce phytohormones (Costacurta and Vanderleyden, 1995) and to fix atmospheric $\mathrm{N}_{2}$ and hence could promote plant growth (Mantelin and Touraine, 2004). Some Streptomyces species are known to have antagonistic activities against phytopathogens and could provide plant protection (Lehr et al., 2008).

Bacteria closely related to Enterobacter showed higher versatility and were found in the two compartments studied in each plant, light and heavy DNA fractions from rhizosphere soil and root tissues, and may be considered as generalist bacteria (Table 2). These bacteria may have an important function in the carbon cycle and functioning of the rhizosphere, even though they are considered as human opportunistic pathogens. Barrel clover roots were colonized preferentially by Rhizobiales, suggesting that specific recognition, mediated by hostroot-secreted flavonoids (Wasson et al., 2006) may occur with a wide range of rhizobial species. Our data suggest that legumes may contribute to stimulate and preserve rhizobia diversity and reservoir in soils.

Bacteria closely related to Myхососсиs and Sphingobacteria, preferentially colonized roots of all four plants (Table 2), indicate their ability to attach and compete for nutrients and space on the root. In contrast, bacteria closely related to sphingomonads were associated only with the rhizosphere of monocotyledons, wheat and maize (Table 2), as observed by Hashidoko et al. (2007) using DNA arrays and Kawahara et al. (1994), who detected sphingomonads in ears of rice and other Gramineae plants, suggesting adaptation to growth on monocotyledons.

Bacteria closely related to Burkholderia and Variovorax species specifically colonized maize and rape roots, respectively (Table 2), and may be considered as specialists (Table 2). Differences between communities associated with the four plant species were more pronounced on root tissues than in rhizosphere soil (Supplementary Figure S3C) and results provide evidence that different plant species select different bacterial communities on their root tissues.

\section{Conclusion}

The continuous labelling of plant is an adequate labelling to evidence the high power of plants through root exudates on SOM degradation, as many bacterial species were stimulated independently from root exudates. However, the long incubation period of plants under ${ }^{13} \mathrm{CO}_{2}$ may result in a labelling of not only primary consumers of rootderived carbon but also of those rhizobacteria that consumed metabolites released by the primary consumers. Future studies employing RNA-SIP and pulse labelling will enable temporal analysis of the flow of root-derived carbon through rhizosphere microbial communities and differentiation of primary and secondary utilizers of root-derived carbon, as demonstrated by Rangel-Castro et al. (2005), Lu et al. (2006) and Vandenkoornhuyse et al. (2007).

In our study, we analysed, by sequencing, only some bands, which presented high relative intensity 
and which discriminated between heavy and light DNA fractions. Indeed, for future studies to characterize total bacterial communities associated with each plant rhizosphere and to evaluate richness and abundance of each bacterial species, pyrosequencing of light and heavy DNA fraction will be more adequate. Moreover, to get consistent information on bacterial functions and role in the rhizsophere, expression analysis of key genes involved in important functions is necessary.

In conclusion, our results show that the roots of four plant species were colonized by different bacterial populations through the assimilation of root exudates, whereas bacteria inhabiting the rhizosphere soil were less different. A high contribution of the rhizosphere to the $\mathrm{C}$ dynamic in soils was demonstrated by the high diversity of bacterial populations using root exudates and those growing at the expense of SOM, and the results also demonstrate the assimilation of exudates by human pathogens in addition to plant beneficial organisms.

\section{Acknowledgements}

We thank the Groupe de Recherche Appliquées en Phytotechnologies of the iBEB/SBVME in CEA Cadarache for labelling facilities. This work was supported by a CNRS PhD grant, COST-STSM-631 program and the GESSOL and Micagro program

\section{References}

Achouak W, Thierry JM, Roubaud P, Heulin T. (2000). Impact of crop management on intraspecific diversity of Pseudomonas corrugata in bulk soil. FEMS Microbiol Ecol 31: 11-19.

Altschul SF, Gish W, Miller W, Myers W, Lipman DJ. (1990). Basic local alignment search tool. J Mol Biol 215: 403-410.

Bais HP, Weir TL, Perry LG, Gilroy S, Vivanco JM. (2006). The role of root exudates in rhizosphere interactions with plants and other organisms. Annu Rev Plant Biol 57: 233-266.

Berg G, Eberl L, Hartmann A. (2005). The rhizosphere as a reservoir for opportunistic human pathogenic bacteria. Environ Microbiol 7: 1673-1685.

Billès G, Bottner P. (1981). Living roots effect on ${ }^{14} \mathrm{C}$-labelled root litter decomposition. Plant Soil 62: 1573-5036.

Costa R, Gotz M, Mrotzek N, Lottmann J, Berg G, Smalla K. (2006). Effects of site and plant species on rhizosphere community structure as revealed by molecular analysis of microbial guilds. FEMS Microbiol Ecol 56: 236-249.

Costacurta A, Vanderleyden J. (1995). Synthesis of phytohormones by plant-associated bacteria. Crit Rev Microbiol 21: 1-18.

Derrien D, Marol C, Balesdent J. (2004). The dynamics of neutral sugars in the rhizosphere of wheat. An approach by ${ }^{13} \mathrm{C}$ pulse-labelling and GC/C/IRMS. Plant Soil 267: 243-253.
Fontaine S, Mariotti A, Abbadie L. (2003). The priming effect of organic matter: a question of microbial competition? Soil Biol Biochem 35: 837-843.

Fromin N, Achouak W, Thiéry JM, Heulin T. (2001). The genotypic diversity of Pseudomonas brassicacearum populations isolated from roots of Arabidopsis thaliana: influence of plant genotype. FEMS Microbiol Ecol 37: 21-29.

Grall S, Manceau C. (2003). Colonization of Vitis vinifera by a green fluorescence protein-labeled, gfp-marked strain of Xylophilus ampelinus, the causal agent of bacterial necrosis of grapevine. Appl Environ Microbiol 69: 1904-1912.

Gramss G, Rudeschko O. (1998). Activities of oxidoreductase enzymes in tissue extracts and sterile root exudates of three crop plants, and some properties of the peroxidase component. New Phytol 138: 401-409.

Hashidoko Y, Kitagawa E, Iwahashi H, Purnomo E, Hasegawa T, Tahara S. (2007). Design of sphingomonad-detecting probes for a DNA array, and its application to investigate the behavior, distribution, and source of Rhizospherous sphingomonas and other sphingomonads inhabiting an acid sulfate soil paddock in Kalimantan, Indonesia. Biosci Biotechnol Biochem 7: 1343-1351.

Haichar FZ, Achouak W, Christen R, Heulin T, Marol C, Marais MF et al. (2007). Identification of cellulolytic bacteria in soil by stable isotope probing. Environ Microbiol 9: 625-634.

Hertenberger G, Zampach P, Bachmann G. (2002). Plant species affect the concentration of free sugars and free amino acids in different types of soil. J Plant Nutr Soil Sci 165: 557-565.

Kai M, Effmert U, Berg G, Piechulla B. (2007). Volatiles of bacterial antagonists inhibit mycelial growth of the plant pathogen Rhizoctonia solani. Arch Microbiol 187: 351-360.

Kawahara K, Mizuta I, Katabami W, Koizumi M, Wakayama S. (1994). Isolation of Sphingomonas strains from ears of rice and other plants of family Gramineae. Biosci Biotechnol Biochem 58: 600-601.

Kowalchuk GA, Buma DS, de Boer W, Klinkhamer PGL, van Veen JA. (2002). Effects of above-ground species composition and diversity on the diversity of soilborne microorganisms. Antonie Van Leeuwenhoek 81: 509-520.

Kumar R, Pandey S, Pandey A. (2006). Plant roots and carbon sequestration. Curr Science 91: 885-890.

Kuske CR, Ticknor LO, Miller ME, Dunbar JM, Davis JA, Barns SM et al. (2002). Comparison of soil bacterial communities in rhizospheres of three plant specie and the interspaces in an arid grassland. Appl Environ Microbiol 68: 1854-1863.

Kuzyakov Y. (2002). Review: Factors affecting rhizosphere priming effects. J Plant nutr Soil Sci 165: 382-396.

Lehr NA, Schrey SD, Hampp R, Tarkka MT. (2008). Root inoculation with a forest soil streptomycete leads to locally and systemically increased resistance against phytopathogens in Norway spruce. New Phytol 177: 965-976.

Lu Y, Rosencrantz D, Liesack W, Conrad R. (2006). Structure and activity of bacterial community inhabiting rice roots and the rhizosphere. Environ Microbiol 8: $1351-1360$.

Lueders T, Manefield M, Friedrich MW. (2004). Enhanced sensitivity of DNA-and rRNA-based stable isotope 
probing by fractionation and quantitative analysis of isopycnic centrifugation gradients. Environ Microbiol 6: $73-78$.

Lupwayi NZ, Rice WA, Clayton GW. (1998). Soil microbial diversity and commuinty structure under wheat as influenced by tillage and crop rotation. Soil Biol Biochem 30: 1733-1741.

Lynch JM, Whipps JM. (1990). Substrate flows in the rhizosphere. Plant Soil 129: 1-10.

Mantelin S, Touraine B. (2004). Plant growth-promoting bacteria and nitrate availability: impacts on root development and nitrate uptake. J Exp Bot 55: 27-34.

Marilley L, Aragno M. (1999). Phylogenetic diversity of bacterial communities differing in degree of proximity of Lolium perenne and Trifolium repens roots. Appl Soil Ecol 13: 127-136.

McCaig AE, Glover LA, Prosser JI. (2001). Numerical analysis of grassland bacterial community structure under different land management regimes by using $16 \mathrm{~S}$ ribosomal DNA sequence data and denaturing gradient gel electrophoresis banding patterns. Appl Environ Microbiol 67: 4554-4559.

Muyzer G, de Waal EC, Uitterlinden AG. (1993). Profiling of complex microbial populations by denaturing gradient gel electrophoresis analysis of polymerase chain reaction-amplified genes encoding for $16 \mathrm{~S}$ rRNA. Appl Environ Microbiol 59: 695-700.

Neufeld JD, Wagner M, Murrell JC. (2007). Who eats what, where and when? Isotope-labelling experiments are coming of age. ISME J 1: 269-270.

Nunan N, Daniell TJ, Singh BK, Papert A, McNicol JW, Prosser JI. (2005). Links between plant and rhizoplane bacterial communities in grassland soils, characterized using molecular techniques. Appl Environ Microbiol 71: 6784-6792.

Paterson E, Gebbing T, Abel C, Sim A, Telfer G. (2007). Rhizodeposition shapes rhizosphere microbial community structure in organic soil. New Phytol 173: 600-610.

Preston GM. (2004). Plant perceptions of plant growthpromoting Pseudomonas. Phil Trans $R$ Soc Lond $B$ 359: 907-918.

Prosser JI, Rangel-Castro JI, Killhman K. (2006). Studying plant-microbe interactions using stable isotope technologies. Curr Opin Biotechnol 17: 98-102.

Radajewski S, Ineson P, Parekh NR, Murell JC. (2000). Stable isotope probing as a tool in microbial ecology. Nature 403: 646-649.
Rangel-Castro JI, Killham K, Ostle N, Nicol GW, Anderson IC, Scrimgeour CM et al. (2005). Stable isotope probing analysis of the influence of liming on root exudates utilization by soil microorganisms. Environ Microbiol 7: 828-838.

Ranjard L, Lejon DPH, Mougel C, Schehrer L, Merdinoglu D, Chaussod R. (2003). Sampling strategy in molecular microbial ecology: influence of soil sample size on DNA fingerprinting analysis of fungal and bacterial communities. Environ Microbiol 11: 1111-1120.

Schmalenberger A, Kertesz MA. (2007). Desulfurization of aromatic sulfonates by rhizosphere bacteria: high diversity of the asfA gene. Environ Microbiol 9: $535-545$.

Smalla K, Wieland G, Buchner A, Zock A, Parzy J, Kaiser S et al. (2001). Bulk and rhizosphere soil bacterial communities studied by denaturing gradient gel electrophoresis: plant-dependent enrichment and seasonal shifts revealed. Appl Environ Microbiol 67: 4742-4751.

Thioulouse J, Chessel D, Dolédec S, Olivier JM. (1997). ADE-4: a multivariate analysis and graphical display software. Star Comput 7: 75-83.

Treonis AM, Ostle NJ, Stott AW, Primrose R, Grayston SJ, Ineson P. (2004). Identification of groups of metabolically active rhizosphere microorganisms by stable isotope probing of PLFAs. Soil biol Biochem 36: 533-537.

Yang CH, Crowley DE. (2000). Rhizosphere microbial community structure in relation to root location and plant iron nutritional status. Appl Environ Microbiol 66: $335-351$.

Vandenkoornhuyse P, Mahé S, Ineson P, Staddon P, Ostle N, Cliquet JB et al. (2007). Active root-inhabiting microbes identified by rapid incorporation of plant-derived carbon into RNA. Proc Natl Acad Sci USA 104: 16970-16975.

Wang Y, Hsieh YP. (2002). Uncertainties and novel prospects in the study of the soil carbon dynamics. Chemosphere 49: 791-804.

Wasson AP, Pellerone FI, Mathesius U. (2006). Silencing the flavonoid pathway in Medicago truncatula inhibits root nodule formation and prevents auxin transport regulation by Rhizobia. Plant Cell 18: 1617-1629.

Zachow C, Tilcher R, Berg G. (2008). Sugar beet-associated bacterial and fungal communities show a high indigenous antagonistic potential against plant pathogens. Microb Ecol 55: 119-129.

Supplementary Information accompanies the paper on The ISME Journal website (http://www.nature.com/ismej) 